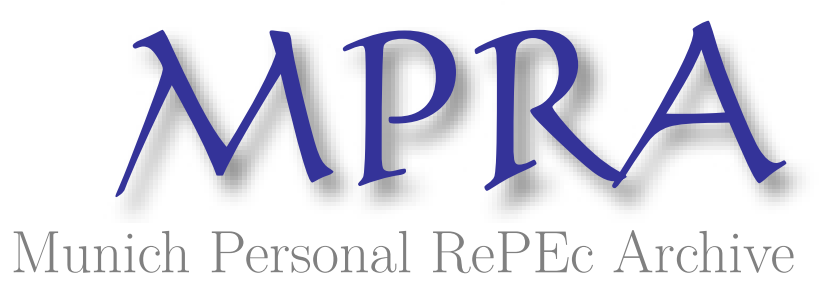

\title{
A Study on Regime Type and Globalization in Simultaneous Equation Framework
}

Mishra, SK

2 January 2018

Online at https://mpra.ub.uni-muenchen.de/83579/

MPRA Paper No. 83579, posted 04 Jan 2018 23:06 UTC 


\title{
A Study on Regime Type and Globalization in Simultaneous Equation Framework
}

\author{
Sudhanshu K. Mishra \\ C-91 (GF) Avantika, Rohini Sector-1, \\ Delhi - 110085 (India) \\ Contact: mishrasknehu@hotmail.com
}

\begin{abstract}
In this study we build a simultaneous equation model in which the measures of different aspects of globalization (attributable to KOF) and different aspects of democracy (attributable to EIU) are related in seven structural equations. A bi-directional relationship between democracy and globalization is visualized. The model is estimated by the conventional 2-SLS as well as a modified 2SLS in which Shapley value regression is used at the second stage of 2-SLS. On the basis of our analysis we conclude the following: (1). Overall, democracy and globalization promote each other and hence there is a bi-directional causality with positive relationships running both ways between democracy and globalization. At a national level, there may be various intermediary conditions that modify the relationship as well as set in motion a complex of positive and/or negative feedbacks to accelerate or retard the pace of globalization and democratization in a country-specific manner. However, when a large number of countries are studied a clear relationship emerges out. (2). There is a need to estimate the structural coefficients of the model cautiously since the regression equations may be suffering from collinearity among the predictor variables. The Shapley value regression based 2-SLS has performed better than the conventional regression in estimating the structural parameters of the model. (3). It is expected that the system methods of estimation of the model would give better results than what are obtained by the single equation methods of estimation of structural parameters of the model.
\end{abstract}

Key words: Simultaneous equations model, Two-Stage Least Squares, Instrumental Variables, Collinearity, Shapley Value Regression, Democracy Index, Globalization Index.

JEL Code: C30, C36, C51, C57, C61, C71, F63 
1. Introduction: The bearing of regime type (that has democracy and authoritarianism at two opposite poles) on globalization are debatable. On the one hand, there are research findings and arguments that suggest a positive influence of democratic attributes in governance on globalization, while, on the other hand, there are empirical studies as well as consorted line of reasoning that favours authoritarian elements in governance to promoting globalization. Reversing the arrow of causality, some scholars have given the logic along with empirical evidences that globalization promotes democracy while some others have reasons to contend that globalization hurts democracy. Since a political regime has more pervasive, direct and explicit effects, the issue of impacts of globalization on democracy has elicited more attention of the scholars.

Economists such as Schumpeter (1950), Lipset (1959) and Hayek (1960) argued that free trade and capital flows, by enhancing the efficiency of resource allocation lead to economic development which fosters demands for democracy. Schwartzman (1998) identified class conflict as the social mechanism linking world-system processes to national political dynamics. In this framework, domestic political structures become part of the evolving transnational fabric of economic relations. Consequently, globalization promotes democracy at the national level which in turn facilitates further globalization in the interest of the dominant world economic system.

Li and Reuveny (2003) studied 127 countries for 26 years (1970-1996) and found that different constituents of globalization affect democracy in different manner not conformal to each other. In their own words: "Trade openness and portfolio investment inflows negatively affect democracy. The effect of trade openness is constant over time while the negative effect of portfolio investment inflows strengthens. FDI inflows positively affect democracy, but the effect weakens over time. The spread of democratic ideas promotes democracy persistently over time."

Sobhan (2003) argued that the process of globalization represents involuntary and often extraneous constraints on the government and the people of a country. Countries with weak democratic institutions and undiversified or externally dependent economies fall prey to the globalization forces. Globalization may favourably help the economies that can diversify and where political institutions are strong enough to protect the interests of the citizens of different sections.

Rudra (2005) covered 59 developing countries for the time period 1972-97 and found that globalization did not directly and unconditionally promote democracy. Increasing exposure to international export and financial markets did lead to improvements in democracy only if safety nets were used simultaneously as a strategy for providing stability and building political support.

In their study that analyses a long series of historical data (1870-2000) for a large number of countries, Eichengreen and Lebang (2006) found a bidirectional causality suggesting the existence of positive relationships running both ways between democracy and globalization.

Acemoglu and Robinson (2006a) showed that the relationship between development and political regime is not a direct one. The political regime type shapes and is also shaped by economic conflict between elites and citizens. Political elites are unlikely to block development when there is a high degree of political competition or when they are highly entrenched. Expected political replacement effect has a direct bearing on the involvement of the elite class in a country in facilitating or discouraging globalization. Acemoglu and Robinson (2006b) also observed that key democratizing forces associated with trade openness depend on country's relative factor endowment.

Milner and Mukherjee (2009) studied 130 developing countries in the period 1975-2002 distributed over different continents. It was found that democracy fostered trade and capital account 
liberalization, while the effect of economic openness on democracy was positive but weak. Neither trade nor capital account liberalization had any statistically significant effects on democratization.

Turyahikayo (2014) examined the impact of globalization on domestic political structures and processes in established, transitional and non-democratic regimes. It revealed that globalization has been used as a tool by the established democracies with strong economies to exploit transitional governments and non-democracies through expanding the range of exploitative investment to bring poorer countries in the ambit of influence. Such an expansion feeds on cheap labour. The destination countries of such investment also work as dumping ground for the industrial waste.

Steiner (2015) studied macro-level dataset on legislative elections in 23 established democracies over the period 1965-2006 to test the hypothesis that higher levels of economic globalization result in lower turnout (for voting). The results of the study emphatically indicated that economic globalization has negative effects on electoral turnout in established democracies on account of reduced party polarization (low dispersion) with limited option with regard to economic policy that also induces citizens to think of contesting parties as having less influence on the economy. In view of this, globalization may have a negative effect on public participation in the political domain.

Nayyar (2015) observed that the relationship between democracy and globalization is dialectical rather than linear or unidirectional. The causation runs in both directions in different spheres whose interaction shapes the outcome.

Stein (2016) investigated into the question whether a sovereign state system, democratic governments, and an integrated global marketplace can coexist. It assessed analytic materialist arguments for their incompatibility and the key assumptions on which they rest. It "describes the extant pressures operating to limit each of the three: how sovereignty and democracy work to constrain globalization, how globalization and sovereignty generate a democratic deficit, and how globalization and democracy lead to limitations upon, and even the transcendence of, sovereignty."

Haffoudhi and Bellakhal (2016) found that the impact of globalization on democracy is demographicregime specific. Countries that overlooked Malthusian constraints fostered democracy, whereas countries with late demographic transitions, suffering yet of Malthusian constraints, famines and chronic under-nutrition or failed to invest in human capital and consequently have had inefficient resource allocation, also failed to promote democracy.

Kollias and Paleologou (2016) studied the relationship between KOF globalization indices and Polity measures of democracy in 110 countries of different income levels (high, medium and low) for the period 1970-2011 and found a positive impact of globalization on democracy, but this was not a universal finding across all income groups since any effect exerted by globalization on democracy may differ depending on a country's attributes.

By means of canonical correlation analysis, Mishra (2017b) studied the relationship between the KOF's aspect-wise indices of globalization and the Economist Intelligence Unit measures of the different constituents of the democracy index for 116 countries distributed over six continents and found that indices of democracy and globalization are highly correlated. The study did not investigate into the causal arrow of the relationship.

This brief review of research suggests that the relationship between globalization and democracy may not be direct. It is mediated by the country-specific institutions, class interests, resource endowments, institutional structure, demographic characteristics, involvement and effectiveness of the national government in proper management of the economy and the polity and so on. 
Depending on mediating forces globalization and democratization may have mutually reinforcing or mutually conflicting relationship.

2. The Present Study: The investigation at hand acknowledges bi-directional causality between globalization and democracy (or the political regime that has full democracy at the one end and authoritarianism at the other). It holds that the regime type affects the extent of globalization and also that globalization affects the regime type tending to favour democratization.

To capture the bi-directional causality mentioned above, this study constructs a simultaneous equation model in which five measures (detailed out below) of different aspects of a regime, ranging between the two poles of full democracy and authoritarianism, aim at explaining six indicators of globalization (detailed out below). Additionally, some of the indicators of globalization influence the overall index of democracy. The globalization indicators as well as the overall index of democracy are, thus, the endogenous variables in the model while the indicators of political regime are predetermined (exogenous) variables.

The Economist Intelligence Unit (EIU), a British business within the Economist Group has published the Democracy Index for 2006, 2008 and 2011 and for every year afterwards up to 2016. The index is based on 60 indicators grouped in five different categories or dimensions of regime ranging from democracy to authoritarianism. These categories are: Electoral process and pluralism (EPP), Functioning of government (FOG), Political participation (PPN), Political culture (PCL) and Civil liberties (CVL), each one measured by an index. These five measures are used as the predetermined (exogenous) variables in the model. In the present work we have used $\mathrm{EPP}_{06}, \mathrm{FOG}_{06}, \mathrm{PPN}_{06}, \mathrm{PCL}_{06}$ and $\mathrm{CVL}_{06}$ for the year 2006, pertaining to 116 countries (Mishra, 2017b).

The five measures of different aspects of democracy (EPP, FOG, PPN, PCL and CVL) mentioned above pertaining to any particular year may be suitably weighted and aggregated to yield an overall index (DI, or the Index of Democracy with the score value in the range of zero to ten). On the basis of the score value (DI) the political systems of different countries may be classified into Full democracies (score value in 8-10 range), Flawed democracies (score value in 6 to below-8 range), Hybrid regimes (score value in 4 to below- 6 range) and authoritarian regimes (score value below 4). This overall index of democracy for the year $2016\left(\mathrm{Dl}_{\mathrm{i} 16} \mathrm{i}=1,2, \ldots, 116\right.$ pertaining to 116 countries) is one of the endogenous variables in the model. We have used $\mathrm{EPP}_{\mathrm{i06}}, \mathrm{FOG}_{\mathrm{i06}}, \mathrm{PPN}_{\mathrm{i06}}, \mathrm{PCL}_{\mathrm{i06}}$ and $\mathrm{CVL}_{\mathrm{i} 06} ; \mathrm{i}=1$ through 116. It may be noted for clarity that $\mathrm{DI}$ for 2006 (i.e. $\mathrm{Dl}_{06}$ ) is neither an endogenous nor a predetermined variable in the model.

As to the measures of different aspects of globalization, we have used the KOF indices for the period 2006-2014 (KOF, 2017). The indices of globalization are six in number. They are: (1). E1 - actual economic flows such as trans-border trade, direct investment and portfolio investment, (2). E2 relaxation of restrictions on trans-border trade as well as capital movement by means of taxation, tariff, etc., (3) S1 - trans-border personal contacts such as degree of tourism, telecom traffic, postal interactions, etc., (4) S2 - flow of information, (5) S3 - cultural proximity, and (6) P - the measure of trans-national political set up. All the six (E1 through P), by a scheme of linear combination, are used to arrive at the overall composite index of globalization (say, $\Gamma$ ) as described in Dreher (2006) and Dreher et al. (2008). Mishra (2017a) uses Almost Equi-Marginal Contribution (AEMC) principle for making a linear combination of globalization aspect indicators $E$ through $P$. The composite index of globalization based on AEMC principle may be denoted by $\mathrm{G}$.

For any particular $i^{\text {th }}$ country (among 116 countries considered in the study at hand) we have $\mathrm{G}$ for 9 years, 2006-2014 that we denote by $G_{i j} ; j=2006$ through 2014 and $i=1$ through 116 . For every $G_{i j}$ we have the associated sub-indices $\left[E 1_{i j}, E 2_{i j}, S 1_{i j}, S 2_{i j}, S 3_{i j}\right.$ and $P_{i j} ; j=2006$ through 2014 and $i=1$ through 
116). From this dataset we have constructed two vectors: $\left[E 1_{i}^{\min }, E 2_{i}^{\min }, S 1_{i}^{\min }, S 2_{i}^{\min } ; S 3_{i}^{\min }, P_{i}^{\min }\right]$ associated with $G_{i}^{\min }=\min _{j}\left(G_{i j} ;_{j \in[2006,2014]}\right) ; i=1,2, \ldots, 116$ that gives us the set of values associated with the lowest extent of globalization experienced by any country during 2006-2014, and similarly, $\left[E 1_{i}^{\max }, E 2_{i}^{\max }, S 1_{i}^{\max }, S 2_{i}^{\max } ; S 3_{i}^{\max }, P_{i}^{\max }\right] \quad$ associated $\quad$ with $\quad G_{i}^{\max }=\max _{j}\left(G_{i j} ;_{j \in[2006,2014]}\right) ; i=$ $1,2, \ldots, 116$ that gives us the set of values associated with the highest extent of globalization experienced by any country during 2006-2014 (Mishra, 2017b). We may call them pessimistic (associated with $G^{\mathrm{min}}$ ) and optimistic (associated with $G^{\text {max }}$ ) vectors of globalization. We have these two vectors as our endogenous variables for estimating the model for pessimistic effects of the indicators of the political regime and optimistic effects of the indicators of the political regime.

Our simultaneous equation model is given in the schematic form as under (t denoting pessimistic or optimistic vector as the case may be):

\begin{tabular}{|c|c|c|c|}
\hline 1. & $E 1_{t}$ & $=$ & $\mathrm{f}\left(\mathrm{E} 2_{\mathrm{t}}, \mathrm{S1}_{\mathrm{t}}, \mathrm{FOG}_{06}, \mathrm{PCL}_{06}, \mathrm{CVL}_{06}\right)$ \\
\hline 2. & $E 2_{t}$ & $=$ & $f\left(S 2_{t}, S_{t}, P_{t}, E P_{06}, P^{\prime} N_{06}\right)$ \\
\hline 3. & $S 1_{t}$ & $=$ & $\mathrm{f}\left(\mathrm{E} 1_{\mathrm{t}}, \mathrm{S3}_{\mathrm{t}}, \mathrm{FOG}_{06}, \mathrm{PCL}_{06}, \mathrm{CVL}_{06}\right)$ \\
\hline 4. & $S 2_{t}$ & $=$ & $\mathrm{f}\left(\mathrm{EL}_{\mathrm{t}}, \mathrm{FOG}_{06}, \mathrm{PCN}_{06}, \mathrm{PCL}_{06}, \mathrm{CVL}_{06}\right)$ \\
\hline 5. & $S 3_{t}$ & $=$ & $\mathrm{f}\left(\mathrm{P}_{\mathrm{t}}, \mathrm{EPP}_{06}, \mathrm{FOG}_{06}, \mathrm{PPN}_{06}, \mathrm{PCL}_{06}\right)$ \\
\hline 6. & $P_{t}$ & $=$ & $\mathrm{f}\left(\mathrm{E} 1_{\mathrm{t}}, \mathrm{E} 2_{\mathrm{t}}, \mathrm{S} 1_{\mathrm{t}}, \mathrm{S} 2_{\mathrm{t}}, \mathrm{S} 3_{\mathrm{t}}\right)$ \\
\hline 7. & $\mathrm{Dl}_{16}$ & $=$ & $f\left(E 2_{t}, S 1_{t}, S 2_{t}, S 3_{t}, P_{t}\right)$ \\
\hline
\end{tabular}

3. Estimation of the Model: There are several methods to estimate a simultaneous equation model that may be primarily classified into two groups: (1) single equation methods, and (2) system methods. The single equation methods are easy to apply and free from the undesirable effects of misspecification of other equations in the model, but they are susceptible to the detrimental effects of disturbances correlated across the equations. The system methods are cumbersome and susceptible to the problems of misspecification of equations in the model, but they perform well even if the disturbances across the equations are correlated. Between the single equation and the system methods of estimation, thus, there is a trade-off between deleterious effects of 'misspecification' and 'correlated residuals across the equations' in the model. Since little is known about correct specification of different equations in our model, we have favoured the single equation method of estimation for ease in computation as well as for avoiding the possible risk in proceeding to the system method of estimation under the circumstances of misspecification. We also do not have reasons to assume the disturbances in the equations to be normally distributed. Under these circumstances we have chosen the Two-Stage Least Squares (2-SLS) method of estimation since it handles instrumental variables in a very natural manner.

The Two-Stage Least Squares for structural Equations: If an econometric model is specified as $\mathrm{YA}+\mathrm{XB}+\mathrm{U}=0$ (where $\mathrm{Y}$ are current endogenous and $\mathrm{X}$ are predetermined variables), the 2-SLS method first obtain the Ordinary Least Squares (OLS) based expected values of $Y$ by the relationship $\hat{Y}=X P$ (called the reduced form) and in order to proceed to the second stage substitute the estimated $\hat{y}$ for observed $\mathrm{y}$ in the equation wherever it is a regressor variable (and not the regressand variable). Thus, among the regressor variables $\hat{y}$ would be used as an instrumental variable (Reiers $\varnothing \mathrm{l}, 1945$ ) representing $y$, while $\mathrm{x}$ is its own instrument. This approach renders the use of OLS at the second stage free from the stochastic regressor problem (Mishra, 2017c).

Possible Collinearity among Regressors at the $2^{\text {nd }}$ Stage and its Treatment: However, since at the second stage, the 2-SLS uses the estimated values of some endogenous variables together with some predetermined variables as regressors, collinearity among the regressor variables may arise. 
This is because the estimated values of endogenous variables are the linear functions of the predetermined variables in the model. Collinearity may affect standard errors of the estimated parameters. Signs of the estimated parameters also be wrong (Smith and Brainard, 1976). Shapley value regression (Lipovetsky, 2006; Mishra, 2016) significantly ameliorates the deleterious effects of collinearity on the estimated parameters. In view of this, we have also used the Shapley value regression at the second stage of 2-SLS and compared the results of this choice with the conventional method that uses OLS at the second stage (Mishra, 2017c) .

4. Empirical Findings: As pointed out earlier, we have used two alternative vectors of globalization measures, the one related to $G^{\min }$ and the other related to $G^{\max }$. Therefore, we have two parallel findings, the one for a pessimistic view and the other for an optimistic view of globalization.

The reduced form coefficients (based on OLS) are given in Table-1.1 and Table-1.2 for pessimistic and optimistic views of globalization, respectively.

\begin{tabular}{|c|c|c|c|c|c|c|c|}
\hline \multicolumn{6}{|c|}{ Table-1.1. Estimated Reduced Form Coefficients Matrix [Transposed P] for Pessimistic Scenario of Globalization } \\
\hline \multirow{2}{*}{$\begin{array}{c}\text { Eqn } \\
\text { No. }\end{array}$} & $\begin{array}{c}\text { Regressand } \\
\text { Variable }\end{array}$ & \multicolumn{2}{|c|}{ Reduced Form Coefficients of Predictor Variables (All Predetermined) Relating to Political Regime } \\
\cline { 3 - 7 } & E1 & -0.09669 & 0.24146 & 0.24643 & 0.18092 & 0.08821 & 23.34796 \\
\hline 1 & E2 & 0.09687 & 0.28829 & -0.00578 & 0.20171 & 0.00678 & 23.07078 \\
\hline 2 & S1 & -0.14461 & 0.08996 & 0.21068 & 0.53211 & 0.30117 & -12.02201 \\
\hline 3 & S2 & -0.04587 & 0.05542 & 0.20342 & 0.31348 & 0.22407 & 21.23889 \\
\hline 4 & S3 & -0.01793 & 0.42558 & 0.21272 & 0.55329 & 0.07899 & -33.44582 \\
\hline 5 & P & 0.00492 & 0.00730 & 0.19940 & 0.15338 & 0.09913 & 46.08075 \\
\hline 6 & DI & 0.07114 & 0.20676 & 0.09848 & 0.23259 & 0.32429 & 3.07933 \\
\hline 7 & & & & & POG & & CONST \\
\hline
\end{tabular}

\begin{tabular}{|c|c|c|c|c|c|c|c|}
\hline \multirow{2}{*}{$\begin{array}{l}\text { Eqn } \\
\text { No. }\end{array}$} & \multirow{2}{*}{$\begin{array}{l}\text { Regressand } \\
\text { Variable }\end{array}$} & \multicolumn{6}{|c|}{ Reduced Form Coefficients of Predictor Variables (All Predetermined) Relating to Political Regime } \\
\hline & & EPP & FOG & PPN & $\mathrm{PCL}$ & CVL & CONST \\
\hline 1 & E1 & 0.12400 & 0.10555 & 0.07432 & 0.20298 & -0.06958 & 42.89204 \\
\hline 2 & E2 & 0.09679 & 0.23024 & -0.02864 & 0.24574 & 0.05692 & 26.76866 \\
\hline 3 & S1 & -0.16699 & 0.12057 & 0.22784 & 0.48374 & 0.30252 & -8.67294 \\
\hline 4 & S2 & -0.07373 & 0.08948 & 0.19270 & 0.30243 & 0.20114 & 25.23083 \\
\hline 5 & S3 & -0.06626 & 0.45089 & 0.36109 & 0.43824 & 0.11419 & -30.03597 \\
\hline 6 & $\mathrm{P}$ & 0.06859 & 0.01120 & 0.17536 & 0.21128 & -0.04321 & 52.97000 \\
\hline 7 & $\mathrm{DI}$ & 0.07114 & 0.20676 & 0.09848 & 0.23259 & 0.32429 & 3.07933 \\
\hline
\end{tabular}

\begin{tabular}{|c|c|c|c|c|c|c|c|c|c|c|c|c|c|}
\hline \multirow{2}{*}{$\begin{array}{l}\text { Eqn } \\
\text { No. }\end{array}$} & \multicolumn{7}{|c|}{ Endogenous Variables: Transposed A Matrix } & \multicolumn{6}{|c|}{ Predetermined Variables: Transposed B Matrix } \\
\hline & E1 & E2 & S1 & S2 & S3 & $\mathrm{P}$ & DI & EPP & FOG & PPN & $\mathrm{PCL}$ & CVL & CONST \\
\hline 1 & -1.0000 & 0.7800 & 1.1911 & 0.0000 & 0.0000 & 0.0000 & 0.0000 & 0.0000 & -0.0906 & 0.0000 & -0.6102 & -0.2750 & 19.6726 \\
\hline 2 & 0.0000 & -1.0000 & 0.0000 & 1.4254 & 0.5535 & -3.5945 & 0.0000 & 0.1899 & 0.0000 & 0.3033 & 0.0000 & 0.0000 & 176.9464 \\
\hline 3 & 1.6709 & 0.0000 & -1.0000 & 0.0000 & -0.9453 & 0.0000 & 0.0000 & 0.0000 & 0.0808 & 0.0000 & 0.7528 & 0.2284 & -82.6508 \\
\hline 4 & 0.0000 & -0.4735 & 0.0000 & -1.0000 & 0.0000 & 0.0000 & 0.0000 & 0.0000 & 0.1919 & 0.2007 & 0.4090 & 0.2273 & 32.1631 \\
\hline 5 & 0.0000 & 0.0000 & 0.0000 & 0.0000 & -1.0000 & 0.7969 & 0.0000 & -0.0219 & 0.4198 & 0.0538 & 0.4311 & 0.0000 & -70.1672 \\
\hline 6 & -0.2108 & -0.6582 & -0.8957 & 1.5402 & 0.5704 & -1.0000 & 0.0000 & 0.0000 & 0.0000 & 0.0000 & 0.0000 & 0.0000 & 41.6162 \\
\hline 7 & 0.0000 & 0.2382 & -2.3633 & 6.0177 & 0.0960 & -3.2436 & -1.0000 & 0.0000 & 0.0000 & 0.0000 & 0.0000 & 0.0000 & -5.9572 \\
\hline
\end{tabular}

At the second stage, we have estimated the structural parameters (A and B) by OLS (i.e. conventional 2-SLS) and presented them in Table-2.1 (pessimistic view) and Table-2.2 (optimistic view). As the proposed alternative at the second stage, we have also estimated the structural parameters by Shapley value regression and presented them in Table-3.1 (pessimistic view) and Table-3.2 (optimistic view). It may be noted that obtaining the coefficients of the Shapley value regression we have to use an efficient optimization method (Lipovetsky, 2006; Mishra, 2016). In the present study, this has been done by the Host-Parasite Co-Evolutionary algorithm, which is a 
powerful biologically inspired population method of global optimization (Mishra, 2013). In Table2.1, Table-2.2, Table-3.1 and Table-3.2, the current endogenous parameters matrix (A) has in the principal diagonal cells minus unity which pertains to the dependent endogenous variable in the equation concerned. A zero in an off-diagonal cell denotes that the endogenous variable has not been included in the particular equation. Similarly, in B matrix, a zero in a cell denotes that the particular predetermined variable has not been included in the equation concerned.

\begin{tabular}{|c|c|c|c|c|c|c|c|c|c|c|c|c|c|}
\hline \multirow{2}{*}{$\begin{array}{l}\text { Eqn } \\
\text { No. }\end{array}$} & \multicolumn{7}{|c|}{ Endogenous Variables: Transposed A Matrix } & \multicolumn{6}{|c|}{ Predetermined Variables: Transposed B Matrix } \\
\hline & E1 & E2 & S1 & S2 & S3 & $P$ & $\mathrm{DI}$ & EPP & FOG & PPN & $\mathrm{PCL}$ & CVL & CONST \\
\hline 1 & -1.0000 & 2.3547 & 0.6222 & 0.0000 & 0.0000 & 0.0000 & 0.0000 & 0.0000 & -0.5116 & 0.0000 & -0.6766 & -0.3918 & -14.7428 \\
\hline 2 & 0.0000 & -1.0000 & 0.0000 & 0.0160 & 0.5052 & 0.0923 & 0.0000 & 0.1251 & 0.0000 & -0.2303 & 0.0000 & 0.0000 & 36.6456 \\
\hline 3 & -0.9095 & 0.0000 & -1.0000 & 0.0000 & 0.8182 & 0.0000 & 0.0000 & 0.0000 & -0.1523 & 0.0000 & 0.3098 & 0.1458 & 54.9108 \\
\hline 4 & 0.0000 & -0.7618 & 0.0000 & -1.0000 & 0.0000 & 0.0000 & 0.0000 & 0.0000 & 0.2649 & 0.1709 & 0.4896 & 0.2445 & 45.6232 \\
\hline 5 & 0.0000 & 0.0000 & 0.0000 & 0.0000 & -1.0000 & -2.6429 & 0.0000 & 0.1150 & 0.4805 & 0.8245 & 0.9966 & 0.0000 & 109.9563 \\
\hline 6 & 1.2483 & -0.6065 & -0.0036 & 0.4164 & -0.0394 & -1.0000 & 0.0000 & 0.0000 & 0.0000 & 0.0000 & 0.0000 & 0.0000 & 3.9434 \\
\hline 7 & 0.0000 & 0.8967 & -2.2264 & 4.6809 & -0.3119 & -0.9095 & -1.0000 & 0.0000 & 0.0000 & 0.0000 & 0.0000 & 0.0000 & -119.7295 \\
\hline
\end{tabular}

\begin{tabular}{|c|c|c|c|c|c|c|c|c|c|c|c|c|c|}
\hline \multirow{2}{*}{$\begin{array}{l}\text { Eqn } \\
\text { No. }\end{array}$} & \multicolumn{7}{|c|}{ Endogenous Variables: Transposed A Matrix } & \multicolumn{6}{|c|}{ Predetermined Variables: Transposed B Matrix } \\
\hline & E1 & E2 & S1 & $\mathrm{S} 2$ & S3 & $P$ & DI & EPP & FOG & PPN & $\mathrm{PCL}$ & CVL & CONST \\
\hline 1 & -1.0000 & 0.2246 & 0.1801 & 0.0000 & 0.0000 & 0.0000 & 0.0000 & 0.0000 & 0.1058 & 0.0000 & 0.1413 & 0.0857 & -41.2332 \\
\hline 2 & 0.0000 & -1.0000 & 0.0000 & 0.1921 & 0.1235 & 0.2956 & 0.0000 & 0.0669 & 0.0000 & 0.1025 & 0.0000 & 0.0000 & -47.4994 \\
\hline 3 & 0.3173 & 0.0000 & -1.0000 & 0.0000 & 0.1711 & 0.0000 & 0.0000 & 0.0000 & 0.1374 & 0.0000 & 0.2075 & 0.1146 & -52.7262 \\
\hline 4 & 0.0000 & 0.2622 & 0.0000 & -1.0000 & 0.0000 & 0.0000 & 0.0000 & 0.0000 & 0.1158 & 0.1397 & 0.1682 & 0.1077 & -45.3551 \\
\hline 5 & 0.0000 & 0.0000 & 0.0000 & 0.0000 & -1.0000 & 0.6622 & 0.0000 & 0.1198 & $0.228 \mathrm{I}$ & 0.2233 & 0.2903 & 0.0000 & -95.9363 \\
\hline 6 & 0.1334 & 0.1300 & 0.0993 & 0.1444 & 0.0706 & -1.0000 & 0.0000 & 0.0000 & 0.0000 & 0.0000 & 0.0000 & 0.0000 & -31.8045 \\
\hline 7 & 0.0000 & 0.3241 & 0.2197 & 0.2931 & 0.1585 & 0.4340 & -1.0000 & 0.0000 & 0.0000 & 0.0000 & 0.0000 & 0.0000 & -84.8041 \\
\hline
\end{tabular}

\begin{tabular}{|c|c|c|c|c|c|c|c|c|c|c|c|c|c|}
\hline \multirow{2}{*}{$\begin{array}{l}\text { Eqn } \\
\text { No. }\end{array}$} & \multicolumn{7}{|c|}{ Endogenous Variables: Transposed A Matrix } & \multicolumn{6}{|c|}{ Predetermined Variables: Transposed B Matrix } \\
\hline & E1 & E2 & S1 & S2 & S3 & $P$ & $\mathrm{DI}$ & EPP & FOG & PPN & $\mathrm{PCL}$ & $\mathrm{CVL}$ & CONST \\
\hline 1 & -1.0000 & 0.1783 & 0.1106 & 0.0000 & 0.0000 & 0.0000 & 0.0000 & 0.0000 & 0.0740 & 0.0000 & 0.0929 & 0.0614 & -30.2465 \\
\hline 2 & 0.0000 & -1.0000 & 0.0000 & 0.2071 & 0.1157 & 0.3142 & 0.0000 & 0.0693 & 0.0000 & 0.1051 & 0.0000 & 0.0000 & -51.7940 \\
\hline 3 & 0.4186 & 0.0000 & -1.0000 & 0.0000 & 0.1708 & 0.0000 & 0.0000 & 0.0000 & 0.1327 & 0.0000 & 0.2071 & 0.1117 & -62.6993 \\
\hline 4 & 0.0000 & 0.2502 & 0.0000 & -1.0000 & 0.0000 & 0.0000 & 0.0000 & 0.0000 & 0.1087 & 0.1289 & 0.1635 & 0.0969 & -44.1332 \\
\hline 5 & 0.0000 & 0.0000 & 0.0000 & 0.0000 & -1.0000 & 0.7641 & 0.0000 & 0.1297 & 0.2512 & 0.2468 & 0.2919 & 0.0000 & -109.4473 \\
\hline 6 & 0.1968 & 0.1237 & 0.0862 & 0.1179 & 0.0599 & -1.0000 & 0.0000 & 0.0000 & 0.0000 & 0.0000 & 0.0000 & 0.0000 & -35.4534 \\
\hline 7 & 0.0000 & 0.3319 & 0.2273 & 0.3195 & 0.1487 & 0.4421 & $\begin{array}{l}-1.0000 \\
\end{array}$ & 0.0000 & 0.0000 & 0.0000 & 0.0000 & 0.0000 & -92.4073 \\
\hline
\end{tabular}

\begin{tabular}{|l|l|c|c|c|c|c|c|c|}
\hline \multicolumn{8}{|c|}{ Table-4.1. R-Square Values for different equations at different stages of 2-SLS (Pessimistic Scenario) } \\
\hline Stage & Estimation & EQN-1 & EQN-2 & EQN-3 & EQN-4 & EQN-5 & EQN-6 & EQN-7 \\
\hline First & Reduced form & 0.37531 & 0.51843 & 0.52306 & 0.51708 & 0.48381 & 0.25075 & 0.89822 \\
\hline Second & Conventional 2-SLS & 0.37531 & 0.51843 & 0.52306 & 0.51708 & 0.48381 & 0.25075 & 0.89822 \\
\hline Second & Shapley Value 2-SLS & 0.36175 & 0.48034 & 0.50404 & 0.50584 & 0.46533 & 0.23918 & 0.84799 \\
\hline
\end{tabular}

\begin{tabular}{|l|l|c|c|c|c|c|c|c|}
\hline \multicolumn{1}{|c|}{ Table-4.2. R-Square Values for different equations at different stages of 2-SLS (Optimistic Scenario) } \\
\hline Stage & \multicolumn{1}{|c|}{ Estimation } & EQN-1 & EQN-2 & EQN-3 & EQN-4 & EQN-5 & EQN-6 & EQN-7 \\
\hline First & Reduced form & 0.24173 & 0.51836 & 0.51797 & 0.50351 & 0.48426 & 0.28982 & 0.89822 \\
\hline Second & Conventional 2-SLS & 0.24173 & 0.51836 & 0.51797 & 0.50351 & 0.48426 & 0.28982 & 0.89822 \\
\hline Second & Shapley Value 2-SLS & 0.22952 & 0.48162 & 0.49500 & 0.49216 & 0.47196 & 0.27350 & 0.83577 \\
\hline
\end{tabular}

In Table-4.1 and Table-4.2 we have presented the $\mathrm{R}^{2}$ obtained for different equations for pessimistic and optimistic views of globalization, respectively. It is seen that conventional 2-SLS at the second stage gives the $R^{2}$ values that are identical to those obtained for the reduced form equations. However, the $R^{2}$ values for the proposed 2-SLS (in which OLS is replaced by the Shapley value regression) are a little smaller than those given by the conventional 2-SLS based on OLS. This cost 
has to be paid for treating the collinearity problem that has devastating effects on the coefficients of the structural equations.

\begin{tabular}{|c|c|c|c|c|c|}
\hline \multirow{3}{*}{$\begin{array}{l}\text { Eqn. } \\
\text { No. }\end{array}$} & \multirow{3}{*}{$\begin{array}{c}\text { Endogenous } \\
\text { (Dependent) } \\
\text { Variable }\end{array}$} & \multirow{2}{*}{\multicolumn{2}{|c|}{$\begin{array}{c}\text { Pessimistic Scenario of Globalization } \\
\text { Predictor Variables }\end{array}$}} & \multirow{2}{*}{\multicolumn{2}{|c|}{$\begin{array}{c}\text { Optimistic Scenario of Globalization } \\
\text { Predictor Variables }\end{array}$}} \\
\hline & & & & & \\
\hline & & Endogenous & Predetermined & Endogenous & Predetermined \\
\hline 1 & E1 & - & FOG, PCl, CVL & - & FOG, $\mathrm{PCl}, \mathrm{CVL}$ \\
\hline 2 & E2 & $\mathrm{P}$ & - & - & PPN \\
\hline 3 & S1 & S3 & - & E1 & FOG \\
\hline 4 & S2 & E2 & - & E2 & - \\
\hline 5 & S3 & - & EPP & $\mathrm{P}$ & - \\
\hline 6 & $\mathrm{P}$ & $\mathrm{E} 1, \mathrm{E} 2, \mathrm{~S} 1$ & - & $\mathrm{E} 2, \mathrm{~S} 1, \mathrm{~S} 3$ & - \\
\hline 7 & $\mathrm{DI}_{16}$ & $\mathrm{~S} 1, \mathrm{P}$ & - & S1, S3, P & - \\
\hline
\end{tabular}

In Table-5 we present the list of predictor variables (equation-wise) that have negatively signed structural coefficients estimated by the conventional 2-SLS. In the first equation (for E1) the democracy measures FOG (Functioning of Government), PCL (political Culture) and CVL (Civil Liberties) have negative sign. This is for both pessimistic and optimistic views of globalization. In the second equation $\mathrm{P}$ (political measure of globalization) or PPN (Political Participation) adversely affect E2 (relaxation of constraints on trans-border flow of goods, services and finance). In equation \#3 trans-border personal contacts (S1) are adversely affected by cultural proximity (S3), trans-border flow of goods, services and finance (E1) or the Functioning of the Government (FOG). In equation \#4, follow of information (S2) is adversely affected by relaxation of restrictions on trans-border trade and flow of finance (E2). In equation \#4, cultural proximity (S3) is adversely affected by electoral process and pluralism (EPP) or political set up for enhancing globalization (P). In equation \#6, the political set up for enhancing globalization is adversely affected by trans-border flow of goods, services and finance (E1), relaxation for restrictions on trans-border trade etc. (E2), trans-border personal contacts and movement of people (S1) or trans-border cultural proximity (S3). It may be noted that most of these (negative) relationships are unexpected and misleading. They also indicate that different measures of globalization are not in concordance with each other. As to the final equation (\#7 for $\mathrm{DI}_{16}$ ), trans-border personal contacts and movement of people (S1), political set up for promoting globalization (P) and/or cultural proximity (S3) adversely affect democratization.

In contrast, a perusal of Table-3.1 and Table-3.2 (the structural coefficient matrices $A^{\prime}$ and $B^{\prime}$ obtained by the proposed Shapley value regression at the second stage) suggests that the coefficients associated with endogenous as well as predetermined variables (off-diagonal elements of $A^{\prime}$ and the elements $B^{\prime}$ - except the constant term) are all positive. They suggest that globalization measures are concordant with each other and the democratic regimes promote globalization. These results are in consonance with the research findings elsewhere (Mishra, 2017b). We also find that $\mathrm{DI}_{16}$ is positively affected by all predictor variables included in equation \#7, indicating that globalization promotes democratization.

The contrasting results obtained by the conventional 2-SLS and the proposed Shapley value based 2SLS indicate that neither data nor the specification in our model were responsible for the unexpected results provided by the conventional 2-SLS, but the problem was created by collinearity at the second stage of the 2-SLS. A treatment of the problem of collinearity by using the Shapley value regression at the second stage of 2-SLS has rendered the results that are conformal to our expectation based on reasoned and realistic ground.

In Table-6.1 and Table-6.2 we present the correlation matrices of disturbances across the equations. A larger magnitude of correlation in an off-diagonal cell indicates cross correlation of residuals that may affect the efficiency of an equation method of estimation and prompt to seek for an application 
of any system method of estimation. A perusal of the elements of correlation matrices reveals that while for $\mathrm{Dl}_{16}$ the cross correlations are often very small (irrespective of the view of globalization pessimistic or optimistic, and the method of estimation - conventional or Shapley value regression based), this is only partially (but dominantly) true of $\mathrm{P}$ (the political dimension of globalization). However, this is not so for the economic (E1 and E2) and social (S1, S2 and S3) indicators of globalization in which most of the correlation coefficients are significantly large in magnitude.

\begin{tabular}{|c|c|c|c|c|c|c|c|c|c|c|c|c|c|c|c|}
\hline \multicolumn{16}{|c|}{$\begin{array}{l}\text { Table-6.1. Correlation Among Residuals At Stage-2 of Conventional and Shapley Value Based 2-SLS } \\
\qquad \text { ( Pessimistic Scenario of Globalization) }\end{array}$} \\
\hline \multirow{2}{*}{ Eqn } & \multirow{2}{*}{$\begin{array}{l}\text { End } \\
\text { Var }\end{array}$} & \multicolumn{7}{|c|}{ Conventional 2-SLS } & \multicolumn{7}{|c|}{ Shapley Value based 2-SLS } \\
\hline & & E1 & E2 & S1 & S2 & S3 & $P$ & $\mathrm{Dl}_{16}$ & E1 & E2 & S1 & S2 & S3 & $P$ & $\mathrm{Dl}_{16}$ \\
\hline 1 & E1 & 1.000 & 0.387 & 0.575 & 0.560 & 0.280 & -0.186 & 0.066 & 1.000 & 0.354 & 0.564 & 0.551 & 0.274 & -0.180 & 0.008 \\
\hline 2 & E2 & 0.387 & 1.000 & 0.517 & 0.563 & 0.472 & -0.021 & 0.072 & 0.354 & 1.000 & 0.458 & 0.509 & 0.479 & -0.050 & 0.073 \\
\hline 3 & S1 & 0.575 & 0.517 & 1.000 & 0.660 & 0.466 & $\begin{array}{c}-0.199 \\
\end{array}$ & 0.038 & 0.564 & 0.458 & 1.000 & 0.669 & 0.456 & -0.189 & -0.041 \\
\hline 4 & S2 & 0.560 & 0.563 & 0.660 & 1.000 & 0.543 & 0.098 & -0.056 & 0.551 & 0.509 & 0.669 & 1.000 & 0.529 & $\begin{array}{l}0.103 \\
\end{array}$ & $\begin{array}{l}-0.087 \\
\end{array}$ \\
\hline 5 & S3 & 0.280 & 0.472 & 0.466 & 0.543 & 1.000 & 0.390 & $\begin{array}{c}-0.047 \\
\end{array}$ & 0.274 & 0.479 & 0.456 & 0.529 & 1.000 & 0.359 & $\begin{array}{c}-0.102 \\
\end{array}$ \\
\hline 6 & $\mathrm{P}$ & -0.186 & -0.021 & $\begin{array}{l}-0.199 \\
\end{array}$ & 0.098 & 0.390 & 1.000 & 0.078 & -0.180 & -0.050 & $\begin{array}{c}-0.189 \\
\end{array}$ & 0.103 & 0.359 & 1.000 & 0.085 \\
\hline 7 & $\mathrm{Dl}_{16}$ & 0.066 & 0.072 & 0.038 & -0.056 & -0.047 & 0.078 & 1.000 & 0.008 & 0.073 & -0.041 & -0.087 & -0.102 & 0.085 & 1.000 \\
\hline
\end{tabular}

\begin{tabular}{|c|c|c|c|c|c|c|c|c|c|c|c|c|c|c|c|}
\hline \multicolumn{16}{|c|}{$\begin{array}{l}\text { Table-6.I. Correlation Among Residuals At Stage-2 of Conventional and Shapley Value Based 2-SLS } \\
\text { (Optimistic Scenario of Globalization) }\end{array}$} \\
\hline \multirow{2}{*}{ Eqn } & \multirow{2}{*}{$\begin{array}{l}\text { End } \\
\text { Var }\end{array}$} & \multicolumn{7}{|c|}{ Conventional 2-SLS } & \multicolumn{7}{|c|}{ Shapley Value based 2-SLS } \\
\hline & & E1 & E2 & S1 & S2 & S3 & $P$ & $\mathrm{Dl}_{16}$ & E1 & E2 & S1 & S2 & S3 & $P$ & $\mathrm{Dl}_{16}$ \\
\hline 1 & E1 & 1.000 & 0.347 & 0.553 & 0.509 & 0.205 & -0.224 & 0.139 & 1.000 & 0.315 & 0.526 & 0.494 & 0.187 & -0.204 & 0.097 \\
\hline 2 & E2 & 0.347 & 1.000 & 0.528 & 0.599 & 0.479 & -0.016 & 0.071 & 0.315 & 1.000 & 0.476 & 0.556 & 0.475 & $\begin{array}{c}-0.048 \\
\end{array}$ & 0.093 \\
\hline 3 & S1 & 0.553 & 0.528 & 1.000 & 0.696 & 0.512 & -0.141 & 0.004 & 0.526 & 0.476 & 1.000 & 0.704 & 0.509 & $\begin{array}{l}-0.130 \\
\end{array}$ & -0.081 \\
\hline 4 & S2 & 0.509 & 0.599 & 0.696 & 1.000 & 0.586 & 0.107 & -0.005 & 0.494 & 0.556 & 0.704 & 1.000 & 0.582 & 0.111 & -0.068 \\
\hline 5 & S3 & 0.205 & 0.479 & 0.512 & 0.586 & 1.000 & 0.319 & -0.053 & 0.187 & 0.475 & 0.509 & 0.582 & 1.000 & 0.297 & -0.077 \\
\hline 6 & $P$ & $\begin{array}{c}-0.224 \\
\end{array}$ & -0.016 & -0.141 & 0.107 & 0.319 & 1.000 & 0.134 & -0.204 & -0.040 & -0.130 & 0.111 & 0.297 & 1.000 & 0.066 \\
\hline 7 & $\mathrm{DI}_{16}$ & 0.139 & 0.071 & 0.004 & -0.005 & -0.053 & 0.134 & 1.000 & 0.097 & 0.093 & $-0.08 \mathrm{I}$ & $\begin{array}{c}-0.068 \\
\end{array}$ & $\begin{array}{c}-0.077 \\
\end{array}$ & 0.066 & 1.000 \\
\hline
\end{tabular}

\begin{tabular}{|c|c|c|c|c|c|c|c|c|c|c|c|c|c|c|c|}
\hline \multicolumn{16}{|c|}{ Table-7. Difierence between Correlation Among Residuals of Conventional versus Shapley Value Based 2-SLS } \\
\hline \multirow{2}{*}{ Eqn } & \multirow{2}{*}{$\begin{array}{l}\text { End } \\
\text { Var }\end{array}$} & \multicolumn{7}{|c|}{ Pessimistic Scenario of Globalization } & \multicolumn{7}{|c|}{ Optimistic Scenario of Globalization } \\
\hline & & E1 & E2 & S1 & S2 & S3 & $\mathrm{P}$ & $\mathrm{DI}$ & E1 & E2 & S1 & S2 & S3 & $\mathrm{P}$ & $\mathrm{DI}$ \\
\hline 1 & E1 & 0 & 0.033 & 0.011 & 0.009 & 0.006 & $\begin{array}{c}-0.006 \\
\end{array}$ & 0.058 & 0 & 0.032 & 0.027 & 0.015 & 0.018 & -0.02 & 0.042 \\
\hline 2 & E2 & 0.033 & 0 & 0.059 & 0.054 & -0.007 & 0.029 & -0.001 & 0.032 & 0 & 0.052 & 0.043 & 0.004 & 0.032 & $\begin{array}{l}-0.022 \\
\end{array}$ \\
\hline 3 & S1 & 0.011 & 0.059 & 0 & $\begin{array}{c}-0.009 \\
\end{array}$ & 0.01 & -0.01 & 0.079 & 0.027 & 0.052 & 0 & -0.008 & 0.003 & -0.011 & 0.085 \\
\hline 4 & S2 & 0.009 & 0.054 & $\begin{array}{c}-0.009 \\
\end{array}$ & 0 & 0.014 & -0.005 & 0.031 & 0.015 & 0.043 & -0.008 & 0 & 0.004 & -0.004 & 0.063 \\
\hline 5 & S3 & 0.006 & $\begin{array}{c}-0.007 \\
\end{array}$ & 0.01 & 0.014 & 0 & 0.031 & 0.055 & 0.018 & 0.004 & 0.003 & 0.004 & 0 & 0.022 & 0.024 \\
\hline 6 & $P$ & -0.006 & 0.029 & -0.01 & -0.005 & 0.031 & 0 & $\begin{array}{c}-0.007 \\
\end{array}$ & -0.02 & 0.032 & -0.011 & -0.004 & 0.022 & 0 & 0.068 \\
\hline 7 & DI & 0.058 & -0.001 & 0.079 & 0.031 & 0.055 & -0.007 & 0 & 0.042 & -0.022 & 0.085 & 0.063 & 0.024 & 0.068 & 0 \\
\hline
\end{tabular}

In Table-7 we present the difference between the cross-equation correlation coefficients obtained by the conventional and the Shapley value based 2-SLS. This is for both views of globalization, pessimistic and optimistic. A positive value in the off-diagonal cell indicates that the cross-equation correlation of disturbances obtained by the conventional 2-SLS is stronger than the one obtained by the Shapley value regression based 2-SLS (while the negative value conveys the opposite). For the pessimistic view of globalization, in the upper diagonal cells of the difference matrix $21(=7 x(7-1) / 2)$ elements are there. Out of them only 7 are negative. It conveys that in two-third of cases the Shapley value based 2-SLS may be more efficient than the conventional 2-SLS. For the optimistic view of globalization, there are only 5 negative values in the upper diagonal cells of the difference matrix. It conveys that in (a little over) three-fourth of cases, the Shapley value based 2-SLS may be more efficient than the conventional 2-SLS. This also is one of the reasons why we consider that the Shapley value based 2-SLS has given better results than the conventional 2-SLS. 
7. Concluding Remarks: On the basis of our analysis that models the relationship between democracy and globalization in a simultaneous equations framework, we conclude the following: (1). Overall, democracy and globalization promote each other and hence there is a bi-directional causality with positive relationships running both ways between democracy and globalization as envisaged by Eichengreen and Leblang (2006). At a national level, there may be various intermediary conditions (such as institutional and historical factors, relative factor abundance, demographic reasons, influence and the self-interests of the elite class, safety nets for stability and building political support by the national government, etc.) that modify the relationship as well as set in motion a complex of positive and/or negative feedbacks to accelerate or retard the pace of globalization and democratization in a country-specific manner. However, when a large number of countries are studied a clear relationship emerges out. (2). There is a need to estimate the structural coefficients of the model cautiously since the regression equations may be suffering from collinearity among the predictor variables. The Shapley value regression based 2-SLS has performed better than the conventional regression in estimating the structural parameters of the model. (3). It is expected that the system methods of estimation of the model would give better results than what are obtained by the single equation methods of estimation of structural parameters of the model.

\section{References}

Acemoglu, D. and Robinson, J.A. (2006a). Economic Backwardness in Political Perspective. American Political Science Review, 100(1), 115-131.

Acemoglu, D., and Robinson, J. A. (2006b). Economic Origins of Dictatorship and Democracy. Cambridge, Mass: Cambridge University Press.

Dreher, A. (2006). Does Globalization Affect Growth? Evidence from a new Index of Globalization. Applied Economics, 38(10): 1091-1110.

Dreher, A., Gaston, N. and Martens, P. (2008). Measuring Globalisation: Gauging its Consequences. New York: Springer.

Eichengreen, B. and Leblang, D. (2006). Democracy and Globalization. NBER Working Paper 12450. Cambridge, Mass: National Bureau of Economic Research.

Haffoudhi, H. and Bellakhal, R. (2016). Threshold Effect of Globalization on Democracy: The Role of Demography. SSRN: https://ssrn.com/abstract=2906308.

Hayek, F.A. (1960). The Constitution of Liberty. Chicago: University of Chicago Press.

KOF [Konjunkturforschungsstelle or Economic Research Centre of ETH Zurich]. (2017). 2017 Index of globalization. http://globalization.kof.ethz.ch/media/filer_public/2017/04/19/rankings_2017.pdf

Kollias, C. and Paleologou, S.M. (2016). Globalization and Democracy: A Disaggregated Analysis by Income Group. Global Economy Journal, 16(2): 213-228.

Li, Q. and Reuveny, R. (2003). Economic Globalization and Democracy: An Empirical Analysis. British Journal of Political Science, 33(1): 29-54.

Lipovetsky, S. (2006). Entropy Criterion in Logistic Regression and Shapley Value of Predictors. Journal of Modern Applied Statistical Methods, 5(1): 95-106. 
Lipset, S.M. (1959). Some Social Requisites of Democracy: Economic Development and Political Legitimacy. American Political Science Review, 53(1): 69-105.

Milner, H.V. and Mukherjee, B. (2009). Democratization and Economic Globalization. Annual Review Political Science, 12():163-81

Mishra, S.K. (2013). Global Optimization of Some Difficult Benchmark Functions by Host-Parasite Coevolutionary Algorithm", Economics Bulletin, 33(1): 1-18.

Mishra, S.K. (2016). Shapley Value Regression and the Resolution of Multicollinearity. Journal of Economics Bibliography, 3(3): 498-515.

Mishra, S.K. (2017a). Almost Equi-Marginal Principle based Composite Index of Globalization: China, India and Pakistan. Journal of Economic and Social Thought, 4(3): 335-351.

Mishra, S.K. (2017b). Are Democratic Regimes Antithetical to Globalization? Working Paper. SSRN: https://ssrn.com/abstract=3088921.

Mishra, S.K. (2017c). A New Kind of Two-Stage Least Squares Based on Shapley Value Regression. Working Paper, SSRN: https://papers.ssrn.com/sol3/papers.cfm?abstract_id=3094512.

Nayyar, D. (1915). Globalization and Democracy. Brazilian Journal of Political Economy, 35 (3): 388402.

Reiers $\varnothing$ I, O. (1945). Confluence Analysis by Means of Instrumental Sets of Variables. Arkiv for Mathematic, Astronomi, och Fysik. 32A. Uppsala: Almquist \& Wiksells.

Rudra, N. (2005). Globalization and the Strengthening of Democracy in the Developing World. American Journal of Political Science, 49(4): 704-730.

Schumpter, J.A. (1950). Capitalism, Socialism and Democracy. New York: Harper \& Row.

Schwartzman, K.C. (1998). Globalization and democracy. Annual Review of Sociology, 24(1): 159-81.

Smith, G. and Brainard, W. (1976). The Value of a priori Information in Estimating a Financial Model. Journal of Finance, 31(5): 1299-1322.

Sobhan, R. (2003). Globalization and the Challenge to Democracy. International Journal of Development Issues, 2(2): 1-14.

Stein, A.A. (2016). The Great Trilemma: Are Globalization, Democracy, and Sovereignty Compatible? International Theory, 8(2): 297-340.

Steiner, N.D. (2015). Essays on Globalization and Democracy. D. Phil dissertation, vorgelegt dem Fachbereich 02 - Sozialwissenschaften, Medien und Sport der Johannes Gutenberg Univ., Mainz. https://nilssteiner.com/wp-content/uploads/2017/01/Dissertation_Steiner_Introduction-only.pdf

Turyahikayo, E. (2014). The Impact of Globalization on Domestic Political Structures in Established, Transitional and Non-Democracies. Journal of Good Governance and Sustainable Development in Africa, 2(2): 94-109. 